\title{
Do Firms in Polluting Industries Outsource Pollution Abatement Services More? Panel Data Evidence from U.S. Industries
}

\author{
Meng Sun $^{1}$ \\ ${ }^{1}$ School of Business, Beijing Normal University, Beijing, China \\ Correspondence: Meng Sun, School of Business, Beijing Normal University, No. 19 Xinjiekou Wai Street, \\ Beijing, China. Tel: 86-10-8258-2608. E-mail: sunmeng@bnu.edu.cn
}

Received: May 26, 2017

Accepted: June 7, 2017

Online Published: July 10, 2017

doi:10.5539/ijef.v9n8p111

URL: https://doi.org/10.5539/ijef.v9n8p111

\begin{abstract}
This paper analyzes empirical evidence from U.S. manufacturing industries to understand which firms tend to outsource environmental services more. We construct a variable that measures the outsourcing level of pollution abatement employing the contract work cost data in the Pollution Abatement Costs and Expenditures Survey. Utilizing the panel data for 1992-94, the results indicate that firms in less polluting industries tend to outsource more environmental services. Moreover, the results remain robust when we use the 2005 data.
\end{abstract}

Keywords: environmental outsourcing, pollution intensity, transaction costs theory, property rights theory

\section{Introduction}

Abating pollution is key for firms to prevent polluting the environment and to meet more stringent environmental regulations. In so doing, firms have been seeking external pollution abatement services in markets in addition to internal management. By providing these pollution abatement goods and services as upstream suppliers, the "eco-industry" has been growing over time.(Note 1) An interesting question arises: do firms in more polluting industries tend to outsource pollution abatement equipment and services more or less? In this paper, we employ U.S. manufacturing industry data to investigate this question.

We first construct a measure of the outsourcing level of pollution abatement at the industry level in the US. In constructing this measure, we show the importance of environmental outsourcing and the substantial variations across industries. In the literature about outsourcing, the ratio of value-added to sales is usually employed as a cross-industry measure of vertical integration (e.g., Levy, 1985; Macmillan et al., 1986; Harrigan, 1986; Caves \& Bradburd, 1988). However, the outsourcing level of pollution abatement has not been considered.

In this paper, we exploit the variations and investigate whether firms in more polluting industries tend to outsource the pollution abatement equipment and services more. Specifically, we find that pollution intensity has a significant, negative effect on the outsourcing of pollution abatement.

Our analysis builds on well-established transaction-cost theories (see, e.g., Coase, 1937; Williamson, 1971, 1979) and property-rights theories (e.g., Grossman \& Hart, 1986; Hart, 1995). In addition, it is also related to the following literature. An emerging theoretical environmental economics literature has considered the presence of the environmental upstream eco-industry (e.g., Canton et. al., 2008; David \& Sinclair-Desgagne, 2010; Greaker \& Rosendahl, 2008) However, the authors did not explore how polluting firms choose between in-house abatement and outsourcing. One exception is Nimubona and Sinclair-Desgagne (2011), who analyzed the factors that affect a polluter's make-or-buy decision in a general theoretical framework, although their study is not strictly built on the transaction-cost theory and the property-rights theory.

Although the boundaries of pollution abatement for firms have not been discussed empirically, there is a rich literature for understanding what a firm is with fruitful empirical evidence. Lafontaine and Slade (2007) and Klein (2005) surveyed the evidence on vertical integration. Most of the empirical work on the make-or-buy decision adopts the transaction cost framework (e.g., Masten, 1984; Saussier, 2000; Levy, 1985). In the line of the empirical examination of the property-rights theory, some evidence has been found (Acemoglu et. al., 2010; Woodruff, 2002). Furthermore, these two theories have been applied in understanding the boundaries of the multinational firm (i.e., the choice between outsourcing vs. foreign direct investment) (e.g., Nunn \& Trefler, 2013). 
The rest of the paper proceeds as follows. Section 2 discusses the theoretical background. Section 3 presents the data. Section 4 presents the empirical results, and the final section concludes.

\section{Theoretical Discussion}

Our study builds on well-established transaction-cost theories and property-rights theories.

The contracts of pollution abatement outsourcing are complex with uncertainty. The abatement technique is complicated and the abatement plan has to adapt to many aspects of production, including the material inputs, production technology and production capacity. Once a polluting firm changes its production plan and intends to adjust the abatement method, the environmental firm may not be willing to change its products optimally ex post. The environmental firm could hold up its products and bargain for higher payments. Similar cases happen when the output varies in changes in the market demand or supply in the macroeconomic environment or when environmental regulations change, as they all have important consequences in the emissions amounts and types.

The outsourcing of pollution abatement is associated with specific investments. For investments made by an upstream environmental firm to customize an input for the needs of a polluting firm, they are relationship-specific because the value of the investments in customization are higher within the buyer-seller relationship than outside the relationship. For example, the specific asset investments include the special tools such as emission detectors and lab equipment that can be used to detect leaking sources and analyze the pollutants. The environmental firm staff have professional knowledge about utilizing those tools and handling the specific emissions issues, achieved through specialized training or learning-by-doing. These are the specific human capital investment. Disposal equipment and landfill sites are specific for efficient treatment and saving in inventory and transport costs.

Firms in the more polluting industries face more pollution problems, including longer pollution-generating production lines, more types of pollutants, larger volumes of emissions, stronger requirements and even larger violation uncertainty. Given various contingencies in the more polluting industries, there are more difficulties in writing complete contracts. Therefore, the contract incompleteness level is higher for firms in the more polluting industries. In addition, the degree of asset specificity in abating pollution is also higher in more polluting industries. For example, the design and training for abating certain pollutants is useless for firms that do not generate these types of pollutants. Effective abatement of hazardous utilities and industrial pollutants require custom-engineered approaches to meet those specific requirements.

In summary, with a higher level of contractual incompleteness and asset specificity in the more polluting industries, the polluting firms and the upstream firms are more likely to haggle with each other ex post. The costs of writing and administering the contracts (i.e., the transaction costs) are higher, which make integration more likely in the more polluting industries to save on transaction costs. We summarize the prediction from the transaction costs theories in Conjectures 1 and 2.

\section{Conjecture 1: More polluting firms have higher transaction costs for outsourcing pollution abatement than less polluting firms do.}

\section{Conjecture 2: According to transaction costs theories, more polluting firms tend to perform in-house abatement.}

Contractual incompleteness and asset specificity are also central to the property-rights theory. However, the property-right theories emphasize how the allocation of property rights changes ex ante incentives for investment in non-contractible assets.

Consider the eco-industry's product as an input in production. The upstream environmental firm decides what equipment to purchase, how much training capital to invest and how much effort to be put in to improve its efficiency and specificity. Once the environmental firm customizes its equipment or designs for the needs of the polluting firm, those investments are relationship-specific. For the polluting firm that abates in-house, it has ownership of the environmental products no matter whether the bargaining breaks down and has a larger share of the total revenue. However, the environmental firm may underinvest in this case so that the polluting firm has to give the environmental firm more autonomy, which is outsourcing in the extreme, to generate a larger total revenue.

The importance of environmental goods and services relative to other inputs in production can lead to different choices between outsourcing and integration according to the property-rights theory. Pollution abatement services are more important for firms in the more polluting industries. For an increase in the marginal productivity of the environmental firm's investment in the joint surplus, which implies an increase in quasi rent, in these industries, the optimal control rights allocation is to give the environmental firms more autonomy so that 
they would make efficient investments. Therefore, outsourcing is more likely when the surplus generated by the relationship is particularly sensitive to the amount of investment undertaken by the environmental industry based on the property-rights theory.

We summarize the prediction from the property-rights theories in Conjecture 3.

Conjecture 3. According to the property-rights theories, polluting firms tend to outsource environmental abatement services more, comparing to less polluting firms.

As stated by Whinston (2003), the transaction-cost theory and the property-rights theory do not always predict similarly. Concerning our study, which of the two opposing effects dominates is hard to predict. By identifying the causal effect of pollution levels on the outsourcing/integration choices below, we jointly consider these two predictions, which may contribute to the understanding of the two strands of literature.

\section{The Data}

To test the above-mentioned theories, we employ the following equation:

$$
C R_{i t}=\beta_{1} \ln P I_{i t}+\beta_{2} \ln S_{i t}+\beta_{3} \ln H H I_{i}+\beta_{4} \operatorname{lnv} s_{i t}+\beta_{5} \ln K_{i t}+\beta_{6} \ln H_{i t}+\alpha_{i}+T_{t}+\varepsilon_{i t},
$$

where $C R_{i t}$ is a measure of the outsourcing level of the pollution abatement in industry $i$ in year $t$, and $P I_{i t}$ is pollution intensity industry $i$ in year $t$, and $\alpha_{i}$ and $T_{t}$ stand for industry fixed effects and year fixed effects, respectively. The definitions and the construction of the control variables are presented in Section 3.2.

\subsection{Measurement of the Pollution Abatement Outsourcing Level}

The U.S. Census reports survey results regarding "Contract work, leasing, and other purchased services" -which mainly include payments made to private and public service providers for both on-site and off-site pollution abatement activities -- among its operating expenses (PAOC) in its reports of Pollution Abatement Costs and Expenditures (PACE) for 2005, 1994, 1993 and 1992. The following is an example from the 2005 PACE: "a facility hires an environmental consulting company to conduct an emission source test to measure air pollutant emissions from the facility's control device. The contractor costs associated with conducting this source test should be included in pollution abatement operating costs (contract work). The labor costs for facility personnel to supervise and assist in conducting this source test should be included in pollution abatement operating costs (salaries, wages and benefits)."

We measure the outsourcing level of the pollution abatement as the ratio of contract work cost in the total pollution abatement operating cost (PAOC), denoted contract ratio ( $C R$ hereafter). The higher the $C R$ is, the higher is the outsourcing level of pollution abatement. In constructing $C R$, we find that, according to the U.S. data, contract work costs have accounted for a large proportion of total pollution abatement operating costs: of the \$20,677.6 million PAOC, \$5,209.7 million -- roughly one fourth of the PAOC -- is contract work, leasing and other purchased services (2005 U.S. PACE Survey). And there are substantial variations in $C R$ at the industry level, which are illustrated in Table 1 for the three-digit NAICs level of U.S. industries in 2005.

Table 1. The variation of contract ratio across industries (3-digit NAICs)

\begin{tabular}{llll}
\hline Most Outsourcing Industries & Least Outsourcing Industries & $C R$ \\
\hline Industries & $C R$ & Industries & 0.14 \\
\hline Textile product mills & 0.49 & Wood product mfg & 0.16 \\
Food mfg & 0.38 & Printing \& related support activities & 0.18 \\
Machinery mfg & 0.37 & Nonmetallic mineral product mfg & 0.19 \\
Beverage \& tobacco product mfg & 0.37 & Petroleum \& coal products mfg & \\
\hline
\end{tabular}

Note. mfg means manufacturing.

There are two sets of data employed in this work. One is a panel dataset from the 1992-1994 PACE. The other is a cross-industry dataset from the 2005 PACE. The four year data $(2005,1994,1993$ and 1992) are the most complete for our purpose. The contract data were combined with other costs prior to 1992. After 1994, the survey was conducted just twice: 1999 and 2005. In the 1999 PACE, this contract work data were not provided. It is worth noting that the results from these two datasets are not directly comparable because the operating cost categories were not exactly the same. We will run separate regressions utilizing these two sets of data.

\subsection{Constructing the Explanatory Variables}

The main explanatory variable is the pollution intensity $\left(P I_{i t}\right)$. It is measured as the ratio of the pollution abatement operating cost (PAOC) to the value added. It measures the "dirty" level of an industry. 
The variable $S_{i t}$ is measured as the total value of shipments, which is to control for the scale of industry. We also use total employment (emp) as an alternative measure of the scale of industry. $H H I_{i}$ denotes the industry's concentration. The larger an industry's size is and the less concentrated an industry is, the more likely there exists a larger pool of upstream specialized suppliers, which facilitate outsourcing.

$v s_{i t}$ is measured as the ratio of the value added to the total value of shipments, and it denotes the overall outsourcing level of an industry. This variable is related to the degree that an industry is susceptible to potential contracting problems and provides variation across industries in contractibility. A firm that outsources more in general (a lower value of $v s$ ) is more likely to outsource its pollution abatement given the institutional environment of the firm, e.g., the manager's preferences and the legal support team's proficiency (Note 2).

$K_{i t}$ is the capital intensity of an industry which is measured as total real capital stock divided by number of employees. $H_{i t}$ is the skill intensity of an industry which is the ratio of non-production worker wages to total worker wages. Capital-intensive and skilled-labor-intensive industries are usually more likely to produce differentiated goods. The customized production line may be related with specific pollution abatement problems and pollutants, which could influence the pollution abatement outsourcing decision (Note 3).

The data of contract work cost and PAOC are all from the PACE. The data of value added, total value of shipments, real capital stock, production worker wages and total worker wages at the industry level are available in the NBER-CES Manufacturing Industry Database. The data files of "Concentration Ratios in Manufacturing" for 1992 and 2002 are the data sources for HHI (Herfindahl Hirschmann index) that characterizes industry concentration in 1992-1994 and 2005, respectively.

Table 2 presents the summary statistics of the final data for 1992-1994.

Table 2. Descriptive statistics (1992-1994)

\begin{tabular}{lcccc}
\hline & Mean & Standard deviation & Minimum & Maximum \\
\hline $\ln P I$ & 1.06 & -9.60 & -1.95 \\
$\ln S$ & -5.01 & 1.20 & 3.81 & 12.19 \\
$\ln e m p$ & 8.10 & 1.06 & -0.223 & 6.16 \\
$H H I$ & 3.05 & 661.35 & 1 & 2999 \\
$\ln v s$ & 727.29 & 0.28 & -2.12 & -0.18 \\
$\ln K$ & -0.71 & 0.85 & 1.79 & 6.75 \\
$\ln H$ & 4.04 & 0.34 & -3.09 & -0.11 \\
\hline
\end{tabular}

\section{Empirical Results}

\subsection{Results from Panel Data}

The panel data for 1992-94 allow us to control for the bias from omitting cross-section characteristics. The results of the fixed-effect estimations are presented in columns 3.1-3.3 in Table 3.

The estimated coefficient on $\ln P I$ is negative and significant at the $1 \%$ level in column 3.1 in Table 3 . The sizable magnitude and the statistical significance of the estimated coefficients remain when we control for more industrial characteristics in columns 3.2 and 3.3. The results indicate that pollution intensity has a significant, negative effect on the pollution abatement contract ratio (i.e., $C R$ ). That is, firms in less polluting industries are more likely to outsource their pollution abatement. On the flip side, more polluting firms tend to integrate their pollution abatement. The results in column 3.3 in Table 3 indicate that the estimated effect of pollution intensity $(\ln P I)$ on the pollution abatement contract ratio (i.e., $C R$ ) remains robust when we utilize lnemp (the logarithm of total employment) instead of $\ln S$ to control for the scale of industries. The results remain robust in pooled OLS regressions in columns 3.4 and 3.5 in Table 3.

As stated in conjectures 2 and 3, there are two opposing forces determining whether a polluting firm outsources/integrates its pollution abatement. The transaction costs theories highlighted in conjecture 2 predict that the polluting firms would integrate their pollution abatement to save transaction costs, while the property rights theories employed in conjecture 3 predict that polluting firms should outsource their pollution abatement. Our results indicate that the force predicted by the transaction costs theory dominates that predicted by the property rights theory.

The industry concentration $(H H I)$ and the overall outsourcing level of an industry (lnvs) are also found to have negative effects on the pollution abatement contract ratio as predicted although the significance levels are not high (as shown in columns 3.4 and 3.3 respectively). For industries that are less concentrated, these firms could 
benefit from being able to choose from a larger pool of upstream pollution abatement suppliers. Their search costs would be lower, the match with the upstream sellers would be better, and the technology progress developed by the upstream firms would be faster. Therefore, firms in less concentrated industries tend to outsource more and have lower ratios of pollution abatement contract. Because we do not have time-variant data of $H H I$, it cannot be tested in the panel data analysis. The negative estimated coefficient of $\ln v s$ also indicates that firms tend to outsource their pollution abatement more if their overall outsourcing capabilities are higher as predicted. The significant effects of some other industrial characteristics $(\ln S, \ln K$, and $\ln H)$ are not found.

Table 3. Regressions between pollution intensity and the outsourcing level

\begin{tabular}{|c|c|c|c|c|c|}
\hline \multicolumn{6}{|c|}{ Dependent variable: $C R$ at the four-digit SICs level during 1992-94 } \\
\hline \multirow[b]{2}{*}{ Independent Variable } & \multicolumn{5}{|c|}{ Column number } \\
\hline & 3.1 & 3.2 & 3.3 & 3.4 & 3.5 \\
\hline \multirow[t]{2}{*}{$\ln P I$} & $-0.351^{* * *}$ & $-0.358^{* * *}$ & $-0.359^{* * *}$ & $-0.102^{* * *}$ & $-0.100^{* * * *}$ \\
\hline & $(0.029)$ & $(0.030)$ & $(0.030)$ & $(0.011)$ & $(0.011)$ \\
\hline \multirow[t]{2}{*}{$\ln S$} & & -0.022 & & 0.001 & \\
\hline & & $(0.162)$ & & $(0.009)$ & \\
\hline \multirow[t]{2}{*}{ lnemp } & & & 0.109 & & 0.007 \\
\hline & & & $(0.303)$ & & $(0.009)$ \\
\hline \multirow[t]{2}{*}{$H H I$} & & & & $-0.00002^{*}$ & -0.00002 \\
\hline & & & & $(0.00001)$ & $(0.00002)$ \\
\hline \multirow[t]{2}{*}{$\ln v s$} & & -0.339 & $-0.342^{*}$ & -0.009 & -0.011 \\
\hline & & $(0.206)$ & $(0.206)$ & $(0.035)$ & $(0.034)$ \\
\hline \multirow[t]{2}{*}{$\ln K$} & & -0.031 & 0.055 & -0.002 & -0.002 \\
\hline & & $(0.154)$ & $(0.244)$ & $(0.016)$ & $(0.016)$ \\
\hline \multirow[t]{2}{*}{$\ln H$} & & -0.209 & -0.213 & -0.031 & -0.028 \\
\hline & & $(0.209)$ & $(0.209)$ & $(0.029)$ & $(0.029)$ \\
\hline Year Fixed Effects & Yes & Yes & Yes & Yes & Yes \\
\hline Industry Fixed Effects & Yes & Yes & Yes & No & No \\
\hline $\mathrm{R}^{2}$ & 0.115 & 0.108 & 0.103 & 0.12 & 0.123 \\
\hline Observations. & 1171 & 1171 & 1171 & 1150 & 1150 \\
\hline
\end{tabular}

Note. *** Significant at the $1 \%$ level, $* *$ at the $5 \%$ level, and * at the $10 \%$ level. (standard error in parentheses).

\subsection{Robustness Check}

Employing the six-digit level NAICs cross-industry data for 2005, we estimated the effect of pollution intensity on the outsourcing of pollution abatement. The OLS regression results are presented in Table 4. Throughout columns 4.1-4.3, the significant, negative effect of pollution intensity on the outsourcing of pollution abatement in the panel data for 1992-1994 remains robust in the most recent cross-industry data in 2005.

The estimated coefficient on lnvs is negative and significant at the 5\% level. The results mean that a higher degree of overall outsourcing is significantly correlated with the level of outsourcing of pollution abatement. However, the estimated coefficients of other variables are not significant. These are basically consistent with the results using the panel data.

Table 4. Robustness checks for 2005

\begin{tabular}{|c|c|c|c|}
\hline \multicolumn{4}{|c|}{ Dependent variable: $C R$ at the six-digit level of NAICs in 2005} \\
\hline \multirow[b]{2}{*}{ Independent variable } & \multicolumn{3}{|c|}{ Column number } \\
\hline & 4.1 & 4.2 & 4.3 \\
\hline $\ln P I$ & $\begin{array}{c}-0.042^{* * *} \\
(0.006)\end{array}$ & $\begin{array}{c}-0.051^{* * *} \\
(0.009)\end{array}$ & $\begin{array}{c}-0.051^{* * *} \\
(0.008)\end{array}$ \\
\hline $\ln S$ & & $\begin{array}{c}0.003 \\
(0.007)\end{array}$ & \\
\hline lnemp & & & $\begin{array}{c}0.004 \\
(0.008)\end{array}$ \\
\hline$H H I$ & & $\begin{array}{c}0.00001 \\
(0.00001)\end{array}$ & $\begin{array}{c}0.00001 \\
(0.00001)\end{array}$ \\
\hline
\end{tabular}




\begin{tabular}{|c|c|c|c|}
\hline $\ln v s$ & & $\begin{array}{c}-0.054^{* *} \\
(0.028)\end{array}$ & $\begin{array}{c}-0.057^{* *} \\
(0.027)\end{array}$ \\
\hline \multirow[t]{2}{*}{$\ln K$} & & 0.012 & 0.014 \\
\hline & & $(0.012)$ & $(0.012)$ \\
\hline \multirow[t]{2}{*}{$\ln H$} & & -0.019 & -0.018 \\
\hline & & $(0.027)$ & $(0.027)$ \\
\hline $\mathrm{R}^{2}$ & 0.12 & 0.12 & 0.12 \\
\hline Observations. & 358 & 358 & 358 \\
\hline
\end{tabular}

Note. $* * *$ Significant at the $1 \%$ level, $* *$ at the $5 \%$ level, and * at the $10 \%$ level. (standard errors in parentheses).

\section{Conclusion}

In this paper, we find that the pollution intensity has a significant, negative effect on the outsourcing of pollution abatement. The result holds up in 1992-94 as well as in 2005. Our results indicate that the force predicted by the transaction costs theory dominates that predicted by the property rights theory. Therefore, firms in less polluting industries tend to outsource their pollution abatement, while more polluting firms tend to integrate their pollution abatement. The results contribute to the understanding of the literature on outsourcing. There is still much more to be done concerning environmental outsourcing. For instance, empirical examinations at the firm level would be fruitful (currently the firm-level data are not disclosed by the EPA). We leave these issues to future research.

\section{Acknowledgments}

This work was supported by "the Fundamental Research Funds for the Central Universities" (Grant No. SKZZX2013034) in China.

\section{References}

Acemoglu, D., Griffith, R., Aghion, P., \& Zilibotti, F. (2010). Vertical Integration and Technology: Theory and Evidence. Journal of the European Economic Association, 8(5), 989-1033. http://dx.doi.org/10.1111/j.1542-4774.2010.tb00546.x

Antras, P., \& Helpman, E. (2008). Contractual Frictions and Global Sourcing. In E. Helpman, D. Marin, \& T. Verdier (Eds.), The Organization of Firms in a Global Economy. Cambridge, MA: Harvard University Press. http://dx.doi.org/10.4159/9780674038547-001

Canton, J., Soubeyran, A., \& Stahn, H. (2008). Environmental Taxation and Vertical Cournot Oligopolies: How Eco-industries Matter. Environmental and Resource Economics, 40(3), 369-382. http://dx.doi.org/10.1007/s10640-007-9158-8

Caves, R. E., \& Bradburd, R. E. (1988). The Empirical Determinants of Vertical Integration. Journal of Economic Behavior and Organization, 9, 265-79. http://dx.doi.org/10.1016/0167-2681(88)90037-6

Coase, R. (1937). The Nature of the Firm. Economica, 4, 386-405. http://dx.doi.org/10.1111/j.1468-0335.1937.tb00002.x

David, M., \& Sinclair-Desgagne, B. (2010). Pollution Abatement Subsidies and the Eco-industry. Environmental and Resource Economics, 45(2), 271-282. http://dx.doi.org/10.1007/s10640-009-9315-3

Greaker, M., \& Rosendhal, K.E. (2008). Environmental Policy with Upstream Pollution Abatement Technology Firms. Journal of Environmental Economics and Management, 56(3), 246-259. http://dx.doi.org/10.1016/j.jeem.2008.04.001

Grossman, S. J., \& Hart, O. D. (1986). The Costs and Benefits of Ownership: A Theory of Vertical and Lateral Integration. Journal of Political Economics, 94, 691-719. http://dx.doi.org/10.1086/261404

Harrigan, K. R. (1986). Matching Vertical Integration Strategies to Competitive Conditions. Strategic Management Journal, 7, 535-555. http://dx.doi.org/10.1002/smj.4250070605

Hart, O.D. (1995). Firms, Contracts, and Financial Structure. Oxford: Oxford University Press. http://dx.doi.org/10.1093/0198288816.001.0001

Klein, P. G. (2005). The Make-or-Buy Decision: Lessons from Empirical Studies. In C. Menard, \& M. Shirley (Eds.), Handbook of New Institutional Economics. Dordrecht: Springer. http://dx.doi.org/10.1007/0-387-25092-1_18

Lafontaine, F., \& Slade, M. (2007). Vertical Integration and Firm Boundaries: The Evidence. The Warwick Economics Research Paper Series (TWERPS) 799, University of Warwick, Department of Economics. 
http://dx.doi.org/10.1257/jel.45.3.629

Levy, D. (1985). The Transaction Cost Approach to Vertical Integration: An Empirical Examination. Review of Economics and Statistics, 67, 438-445. http://dx.doi.org/10.2307/1925972

MacMillan, I. C., Hambrick, D. C., \& Pennings, J. M. (1986). Uncertainty Reduction and the Threat of Supplier Retaliation: Two Views of the Backward Integration Decision. Organization Studies, 7, 263-278. http://dx.doi.org/10.1177/017084068600700304

Masten, S. E. (1984). The Organization of Production: Evidence from the Aerospace Industry. Journal of Law and Economics, 103-104, 9-24. http://dx.doi.org/10.1086/467071

Nimubona, A. D., \& Sinclair-Desgagne, B. (2011). Polluters and Abaters. Annals of Economics and Statistics, 56(1), 105-125. http://dx.doi.org/10.2307/41615491

Nunn, N., \& Trefler, D. (2013). Incomplete Contracts and the Boundaries of the Multinational Firm. Journal of Economic Behavior and Organization, 94, 330-344. http://dx.doi.org/10.1016/j.jebo.2012.10.004

Saussier, S. (2000). Transaction Costs and Contractual Incompleteness: The Case of Electricitie de France. Journal of Economic Behavior and Organization, 42, 189-206. http://dx.doi.org/10.1016/S0167-2681(00)00085-8

Whinston, M. D. (2003). On the Transaction Cost Determinants of Vertical Integration. Journal of Law, Economics, and Organization, 19, 1-23. http://dx.doi.org/10.1093/jleo/19.1.1

Williamson, O. E. (1971). The Vertical Integration of Production: Market Failure Considerations. American Economic Review, 61, 112-123.

Williamson, O. E. (1979). Transacton Cost Economics: The Governance of Contractual Relations. Journal of Law and Economics, 22, 233-261.

Woodruff, C. (2002). Non-Contractible Investment and Vertical Integration in the Mexican Footwear Industry. $\begin{array}{llll}\text { International Journal of Industrial Organization, } 20, & 1197-1224 .\end{array}$ http://dx.doi.org/10.1016/S0167-7187(01)00085-6

\section{Notes}

Note 1 . Over the last 40 years, the "eco-industry" has come to rival the aerospace and pharmaceutical sectors in size (Nimubona \& Sinclair-Desgagne, 2011).

Note 2. In addition, in the case that polluting industries have bigger facilities and belong to large firms, they are more likely to have headquarters that provide various services to their establishments. This provision of services by headquarters are nonmarket transactions. By controlling for an industry's overall outsourcing, we can alleviate this effect.

Note 3. The direction is hard to be predicted because it is related with both the transaction-cost theory and the property-rights theory.

\section{Copyrights}

Copyright for this article is retained by the author(s), with first publication rights granted to the journal.

This is an open-access article distributed under the terms and conditions of the Creative Commons Attribution license (http://creativecommons.org/licenses/by/4.0/). 